\title{
First- and second-line strategies in chron- ic phase CML including hematopoietic stem cell transplantation
}

\author{
Rüdiger Hehlmann, Susanne Saußele \\ Heidelberg University, Germany
}

Prof. Dr. Dr. h. c. R. Hehlmann, Medizinische Fakultät Mannheim der Universität Heidelberg, Pettenkoferstr. 22, 68169 Mannheim, Germany
Phone: +49(0)621-383-69-32

E-mail: R.Hehlmann@urz.uni-heidelberg.de

\section{Summary}

The review article is dedicated to the main principles of modern therapy in chronic myeloid leukemia (CML). Current treatment options for the chronic phase (CP) CML include Imatinib at standard or high doses (400 to $800 \mathrm{mg} / \mathrm{d}$ ) and second-generation tyrosine kinase inhibitors (2-G TKIs), e. g. dasatinib and nilotinib. Hematopoietic stem cell transplantation (HSCT) is generally considered second or third line. Early SCT may be an option for non-high risk patients with low transplantation risks. According to the German CML Study Group the 10-year survival in CML has continuously improved,up to $85 \%$ with imatinib introduction. Previously, the survivors after busulfan and hydroxyurea were mostly transplant recipients. CML-Study III and IIIA compared allo-SCT with the best available drug treatment. Most authors who applied TKIs in CML, used imatinib, and HSCT (in some clinical situations). According to CML- Study IV the molecular responses (MR) achieved with imatinib in MR2 situations (an analogue of complete cytogenetic remission) may reach $92 \%$ after 10 years of observations. Introduction of the 2G-TKI (dasatinib and nilotinib) is associated with more rapidly occurring and more frequent molecular responses than with imatinib at standard dose (DASISION 5-year final study results, ENESTnd 5-year update). Increased imatinib dosage to $800 \mathrm{mg}$ daily provides more rapid and deep molecular responses, as shown by appropriate meta-analysis of randomized trials, being associated with a $45 \%$ higher probability of achieving MMR after 12 months with IM $800 \mathrm{mg}$ or 2G-TKIs, compared to IM $400 \mathrm{mg}$ ( $\mathrm{p}=0,0088)$.

\section{Second-line strategies}

Switching to second-line TKI treatment and/or allogeneic HSCT is recommended in cases of intolerance or drug re- sistance. E. g., it was concluded in the ENESTcmr Study (Hughes et al., 2014) that such transition caused more molecular responses in terms of BCR-ABL than with permanent imatinib treatment $(p=0,009)$. The best approaches with drug treatment and HSCT at different phases of CML are described in some recent works (Jiang et al., 2011; Jabbour et al., 2011, Khoury et al., 2012). A good efficacy of allo-HSCT was shown in an update of the study by Saussele et al. (2014), with a median follow-up of 78,5 months (Fig. 1). The patients were stratified by risk. In $50-70 \%$ of cases unrelated donors served as a source of transplant. The patients transplanted in 1st chronic phase electively or after resistance to TKI therapy have shown a good 5-year survival (80\%). Interestingly, the survival probability of the patients transplanted early in chronic phase was similar to that of patients' treatment with imatinib only.

\section{Conclusion}

- Current first-line treatment includes imatinib, dasatin$\mathrm{ib}$ and nilotinib.

- The proportion of patients reaching MMR by 12 months is similar with optimized imatinib and second-generation TKIs.

- SCT is an option for the 2nd-line treatment.

- Long-term outcomes after early SCT in chronic phase is similar to the results obtained with imatinib.

- Early HSCT may be considered in non-high risk CP CML patients with low transplantation risk.

\section{Keywords}

chronic myeloid leukemia, chronic phase, therapy, tyrosine kinase inhibitors, hematopoietic stem cell transplantation 


\section{First-line strategies: TKI efficiency in chronic phase of $C M L$}

At present, first-line therapy options in the chronic phase of chronic myeloid leukemia (CML) include imatinib at standard or high doses (400 to $800 \mathrm{mg} / \mathrm{d}$ ) and second-generation tyrosine kinase inhibitors (2 G-TKIs), i. e., dasatinib and nilotinib, especially when the treatment milestones are not reached with imatinib. Hematopoietic stem cell transplantation (HSCT) is generally considered second or third line. More recent data show that early SCT may be an option for non-high risk patients with low transplantation risk [9]. TKI at the optimal doses provide high survival rates (Table 1).

\begin{tabular}{|l|l|l|l|l|}
\hline Drug properties & $\begin{array}{l}\text { Imatinib } \\
400 \mathrm{mg}\end{array}$ & $\begin{array}{l}\text { IM } 800 \mathrm{mg} \\
\text { tolerability adapted }\end{array}$ & $\begin{array}{l}\text { Nilotinib } \\
2 \times 300 \mathrm{mg}\end{array}$ & $\begin{array}{l}\text { Dasatinib } \\
100 \mathrm{mg}\end{array}$ \\
\hline Efficacy & Standard treatment & Acts faster & $\begin{array}{l}\text { Acts faster, } \\
\text { less early progres- } \\
\text { sions }\end{array}$ & $\begin{array}{l}\text { Acts faster, } \\
\text { less early progres- } \\
\text { sions }\end{array}$ \\
\hline Safety & Safe & Safe & Assess risks & Assess risks \\
\hline Survival & $\begin{array}{l}84-86 \% \text { after } 10 \\
\text { years }\end{array}$ & $91-94 \%$ after 5 years & $94 \%$ after 5 years & $91 \%$ after 5 years \\
\hline
\end{tabular}

Table 1. General therapeutic characteristics of tyrosine kinase inhibitors in CML

Results of the German CML Study Group show that survival of CML has continuously improved over time from $10 \%$ after 10 years when busulfan and hydroxyurea were used to $85 \%$ with imatinib (Figure 1). Long term survivors after busul- fan and hydroxyurea are mostly transplant recipients. CMLStudy III and IIIA compare allo-SCT with best available drug treatment. Most studies on TKI in CML have used imatinib, as seen from Table 2 .

\begin{tabular}{|c|c|c|c|c|c|c|}
\hline Study (reference No.) & IM-dose mg & $\mathrm{N}$ & $\begin{array}{l}\text { Age at diag- } \\
\text { nosis, median, } \\
\text { years }\end{array}$ & $5 y r$ survival \% & $\begin{array}{l}\text { 8-10yr } \\
\text { survival \% }\end{array}$ & $\begin{array}{l}\text { Median } \\
\text { observation } \\
\text { time, years }\end{array}$ \\
\hline CML-IV [11] & IM 400-800 & 1536 & 53 & 90 & 86 & 8 (max. 13) \\
\hline IRIS [6] & IM 400 & 553 & 50 & 89 & 85 (8 years) & 8 \\
\hline GIMEMA [18] & IM 400-800 & 559 & 52 & 90 & NA & 5 \\
\hline Hammersmith [5] & IM 400 & 204 & 46,3 & 83 & NA & 3,2 \\
\hline PETHEMA [3] & IM 400 & 210 & 44 & 97,5 & NA & 4,2 \\
\hline TOPS [1] & $\begin{array}{l}\text { IM } 400 \\
\text { IM } 800\end{array}$ & 157319 & $\begin{array}{l}45 \\
48\end{array}$ & $\begin{array}{l}94 \text { (4 years) } \\
93,4 \text { (4 years) }\end{array}$ & NA & $\begin{array}{l}3,5 \\
3,5\end{array}$ \\
\hline MDACC-2014 & $\begin{array}{l}\text { IM } 400 \\
\text { M } 800\end{array}$ & $\begin{array}{l}70 \\
201\end{array}$ & 8.3 & NR & $\begin{array}{l}80 \\
84\end{array}$ & $\begin{array}{l}9,9 \\
(\min .8)\end{array}$ \\
\hline ILTE [8] & IM NR & 832 & $51 a$ & 98 (6 years) & 95 (8 years) & 5,8 \\
\hline ENESTnd [20] & $\begin{array}{l}\text { IM } 400 \\
\text { Nilo } 600\end{array}$ & $\begin{array}{l}283 \\
282\end{array}$ & $\begin{array}{l}46 \\
47\end{array}$ & $\begin{array}{l}92 \\
94\end{array}$ & NA & 5 \\
\hline & Nilo 800 & 281 & 47 & 96 & & \\
\hline DASISION [16] & $\begin{array}{l}\text { IM } 400 \\
\text { Dasa } 100\end{array}$ & $\begin{array}{l}260 \\
259\end{array}$ & $\begin{array}{l}49 \\
46\end{array}$ & $\begin{array}{l}90 \\
91\end{array}$ & NA & 5 \\
\hline \multicolumn{4}{|l|}{ Median (estimate) } & 91 & 84 & \\
\hline
\end{tabular}

Notes: $N R=$ not reported; yr=year; $\min =$ =minimum; $\max .=$ maxiumum; $I M=$ imatinib; Nilo=nilotinib; Dasa=dasatinib Notes: NR=not reported; yr=year; min.=minimum; max=maxiumum; IM=imatinib; Nilo=nilotinib; Dasa=dasatinib

Table 2. Long term results with tyrosine kinase inhibitors in CML 
In some clinical situations, allogeneic HSCT is applied as seen from Table 3, according to: Barrett, Ito [2].

\begin{tabular}{|l|l|l|l|l|}
\hline \multirow{2}{*}{ CML phase } & Clinical situation & TKI and chemotherapy & $\begin{array}{l}\text { HLA typing } \\
\text { and donor }\end{array}$ & $\begin{array}{l}\text { Immediate } \\
\text { allo-SCT }\end{array}$ \\
\hline CP & First failure of imatinib, high risk & Second-line TKI & Yes & No \\
\hline & First failure of nilotinib or dasatinib & Second-line TKI & Yes & Yes \\
\hline & Failure to 2 TKIs & Third-line TKI & Yes & Yes \\
\hline AP & T315I mutation & Ponatinib or omacetaxine & Yes & Yes \\
\hline & TKI naive & TKI 6 chemotherapy & Yes & Yes \\
\hline & TKI naive, without optimal response & Second-line TKI 6 chemotherapy & Yes & Yes \\
\hline BP & TKI pretreated & Second-line TKI 6 chemotherapy & Yes & Yes \\
\hline
\end{tabular}

\section{Table 3. Current HSCT strategies for different CML phases}

According to CML- Study IV molecular responses (MR) achieved with imatinib after 10 years of observations may reach 92\% for MR2 (molecular equivalent to complete cytogenetic remission), $89 \%$ for MMR, $81 \%$ for MR4, $72 \%$ for MR4.5 and 59\% for MR5.

Introduction of the 2G-TKI (dasatinib and nilotinib) is associated with more rapidly occurring and more frequent molecular responses than with imatinib at standard dose (DASISION 5-year final study results, ENESTnd 5-year update).

Increasing the imatinib dose to $800 \mathrm{mg}$ also achieves faster and deeper molecular responses, as seen from comparisons of imatinib 400 and $800 \mathrm{mg} /$ day $[4,7,10,11]$. Hence, dasatinib, nilotinib and dose-optimized imatinib achieve molecular responses faster than imatinib at standard dose.

Several studies were analyzed in a systematic review and meta-analysis of randomized trials [12] comparing imatinib
$400 \mathrm{mg} / \mathrm{d}$ vs. imatinib $800 \mathrm{mg} / \mathrm{d}[1,4,7,10]$, and imatinib $400 \mathrm{mg} / \mathrm{d}$ vs $2 \mathrm{G}-\mathrm{TKI}$ in chronic phase CML $[4,16,19,20]$.

The systematic review shows a $45 \%$ higher probability of achieving MMR after 12 months with IM 800 mg compared to IM $400 \mathrm{mg}(\mathrm{p}=0,0088)$. Efficacy estimated of IM 400 vs. 800 and IM 400 vs. 2G-TKI cannot be compared directly. But given the fairly similar prognostic profiles of the patients of the different trials it can be concluded that MMR rates achieved with IM 800 and 2G-TKI might be comparable.

\section{Second-line strategies}

- In the case of intolerance or resistance change of treatment to 2nd-line TKI or SCT is recommended (for criteria, see Table 4).

- Switching treatment to optimize responses is recommended, if defined milestones are missed (confirmation required).

\begin{tabular}{|l|l|l|}
\hline & ELN & NCCN \\
\hline 3 months & Ph+ >95\% & $\begin{array}{l}\mathrm{Ph}+>35 \% \\
\text { or BCR-ABL }>10 \%\end{array}$ \\
\hline 6 months & $\begin{array}{l}\mathrm{Ph}+>35 \% \\
\text { and / or BCR-ABL }>10 \%\end{array}$ & $\begin{array}{l}\mathrm{Ph}+>35 \% \\
\text { or BCR-ABL }>10 \%\end{array}$ \\
\hline 12 months & $\begin{array}{l}\mathrm{Ph}+>0 \\
\text { and / or BCR-ABL }>1 \%\end{array}$ & $\begin{array}{l}\mathrm{Ph}+>0 \\
\text { or BCR-ABL }>1 \%\end{array}$ \\
\hline
\end{tabular}

Table 4. Milestones for switching of TKI - Definition of "Failure"="Change the treatment"

Some studies tested switching of TKI to achieve time-dependent molecular targets. E.g., in the ENESTcmr Study [13], a comparison was made between imatinib treated patients in CCR switched to nilotinib ( $\mathrm{n}=104)$, vs. imatinib continued ( $\mathrm{n}=103)$. After 2 years $22 \%$ with nilotinib and $9 \%$ with imatinib had undetectable BCR-ABL $(p=0,0087)$.
The TIDEL II Study [23], analyzed imatinib dose escalation to $800 \mathrm{mg}$ or switching to nilotinib, if molecular targets were not reached. $73 \%$ of patients reached a confirmed MMR at 2 years.

Current best SCT practices in CML are based on several recent studies for the patients in chronic, accelerated, and blast phase of the disease $[14,15,17,21,22]$. 


\section{Transplantation options}

A good efficacy of allo-HSCT was shown in an update of the study by Saussele et al. [22], with a median follow-up of 78,5 months (Fig. 1). The patients were stratified by risk according to the EBMT or EURO scores. In 50-70\% of cases unrelated donors served as a source of transplant.

The patients transplanted in 1 st chronic phase electively or after resistance to TKI therapy have shown a good 5-year survival (80\%). HSCT performed in advanced phase of the disease resulted also in high survival rates. The updated matched pair analysis has a median follow-up of 87 months. The survival probability of the patients transplanted early in chronic phase was similar to that of patients with imatinib treatment (Fig. 2)

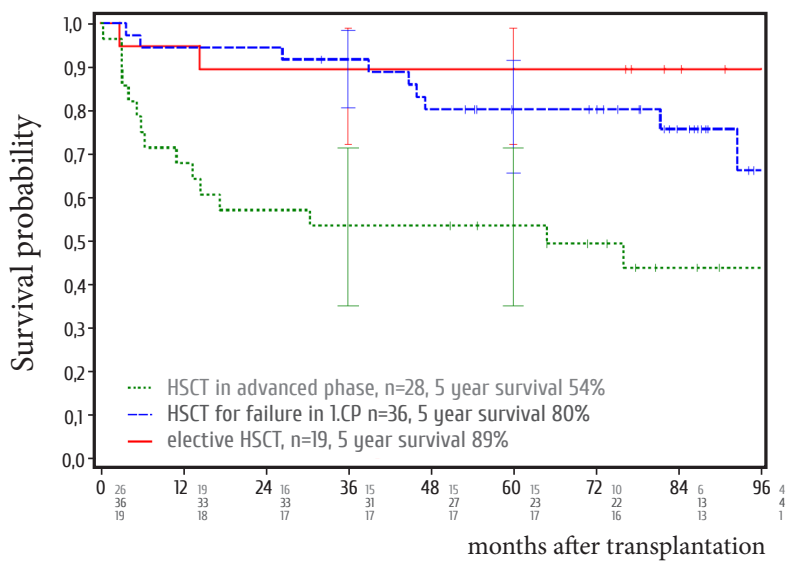

Fig. 1. Survival probabilities in groups of CML patients treated with HSCT [22].

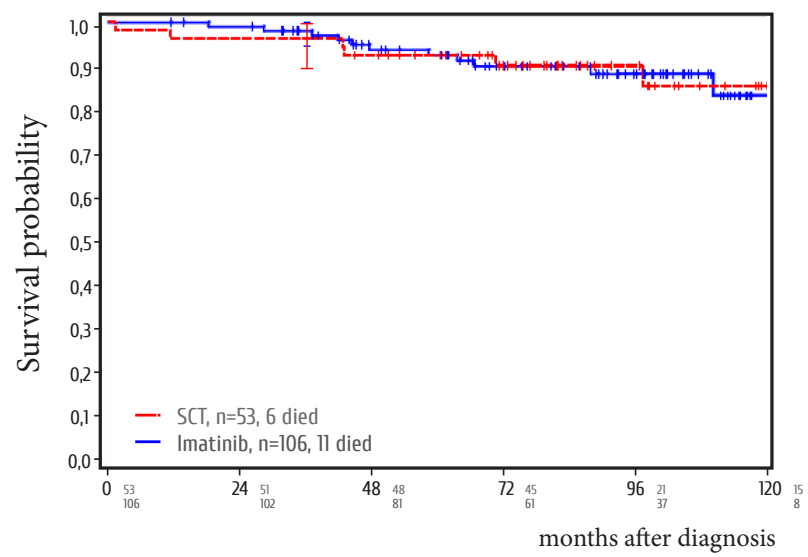

Figure 2. Matched pair analysisof survival in chronic phase with imatinib vs. HSCT.

\section{Conclusions}

- Current first-line treatment includes imatinib, dasatinib and nilotinib.

- MMR at 12 months is achieved faster with dose-optimized Imatinib than with IM-400.
- The proportion of patients reaching MMR by 12 months is similar to optimized imatinib and second-generation TKIs.

- SCT may be considered the 1st line in selected patients.

- SCT is an option for the 2nd-line treatment.

- Long-term outcomes after early SCT in chronic phase is similar to the results obtained with Imatinib.

- Early SCT may be considered in non-high risk patients with low transplantation risk.

\section{Acknowledgements}

The authors are much appreciated to Dr. Alexey B. Chukhlovin for valuable assistance with preparation of the manuscript.

\section{References}

1. Baccarani M, Druker BJ, Branford S, Kim DW, Pane F, Mongay L, Mone M, Ortmann CE, Kantarjian HM, Radich JP, Hughes TP, Cortes JE, Guilhot F. Long-term response to imatinib is not affected by the initial dose in patients with Philadelphia chromosome-positive chronic myeloid leukemia in chronic phase: final update from the tyrosine kinase inhibitor optimization and selectivity (TOPS) study. Int J Hematol. 2014; 99 (5): 616-624.

2. Barrett AJ, Ito S. The role of stem cell transplantation for chronic myelogenous leukemia in the 21 st century. Blood. 2015; 125 (21): 3230-3235.

3. Cervantes F, Lopez-Garrido P, Montero MI, Jonte F, Martinez J, Hernandez-Boluda JC, Calbacho M, Sureda A, PerezRus G, Nieto JB, Perez-Lopez C, Roman-Gomez J, Gonzalez M, Pereira A, Colomer D. Early intervention during imatinib therapy in patients with newly diagnosed chronic-phase chronic myeloid leukemia: a study of the Spanish PETHEMA group. Haematologica. 2010; 95 (8): 1317-1324.

4. Cortes JE, Baccarani M, Guilhot F, Druker BJ, Branford S, Kim DW, Pane F, Pasquini R, Goldberg SL, Kalaycio M, Moiraghi B, Rowe JM, Tothova E, De Souza C, Rudoltz M, Yu R, Krahnke T, Kantarjian HM, Radich JP, Hughes TP. Phase III, randomized, open-label study of daily imatinib mesylate $400 \mathrm{mg}$ versus $800 \mathrm{mg}$ in patients with newly diagnosed, previously untreated chronic myeloid leukemia in chronic phase using molecular end points: tyrosine kinase inhibitor optimization and selectivity study. Clin Oncol. 2010; 28 (3): 424-430.

5. de Lavallade H, Apperley JF, Khorashad JS, Milojkovic D, Reid AG, Bua M, Szydlo R, Olavarria E, Kaeda J, Goldman JM, Marin D. Imatinib for newly diagnosed patients with chronic myeloid leukemia: incidence of sustained responses in an intention-to-treat analysis. J Clin Oncol 2008; 26 (20): 3358-3363.

6. Deininger M, O'Brien SG, Guilhot F, Goldman JM, Hochhaus A, Hughes TP, Radich JP, Hatfield AK, Mone M, Filian J, Reynolds J, Gathmann I, Larson RA, Druker BJ. et al. International randomized study of Interferon Vs STI571 (IRIS) 8-year follow up: sustained survival and low risk for progression or events in patients with newly diagnosed chronic myeloid leukemia in chronic phase 
(CML-CP) treated with Imatinib. Proc. ASH 2009. Abstr. \#1126.

7. Deininger MW, Kopecky KJ, Radich JP, Kamel-Reid S, Stock W, Paietta E, Emanuel PD, Tallman M, Wadleigh M, Larson RA, Lipton JH, Slovak ML, Appelbaum FR, Druker BJ. Imatinib $800 \mathrm{mg}$ daily induces deeper molecular responses than Imatinib $400 \mathrm{mg}$ daily: results of SWOG S0325, an intergroup randomized PHASE II trial in newly diagnosed chronic phase chronic myeloid leukaemia. Br J Haematol. 2014; 164 (2): 223-232.

8. Gambacorti-Passerini C, Antolini L, Mahon FX, Guilhot F, Deininger M, Fava C, Nagler A, Della Casa CM, Morra E, Abruzzese E, D'Emilio A, Stagno F, le Coutre P, Hurtado-Monroy R, Santini V, Martino B, Pane F, Piccin A, Giraldo P, Assouline S, Durosinmi MA, Leeksma O, Pogliani EM, Puttini M, Jang E, Reiffers J, Valsecchi MG, Kim DW. Multicenter independent assessment of outcomes in chronic myeloid leukemia patients treated with imatinib. J Natl Cancer Inst. 2011; 103 (7): 553-561.

9. Gratwohl A, Pfirrmann M, Zander A, Kroeger N, Beelen D, Novotny J, et al. for the SAKK and the German CML Study Group. Long-term outcome of patients with newly diagnosed chronic myeloid leukemiaFA randomized comparison of stem cell transplantation with drug treatment. Leukemia. 2015 Oct 14. doi: 10.1038/leu. 2015.281.

10. Hehlmann R, Lauseker M, Jung-Munkwitz S, Leitner A, Mueller MC, Pletsch N, Proetel U, Haferlach C, Schlegelberger B, Balleisen L, et al. Tolerability-adapted imatinib $800 \mathrm{mg} / \mathrm{d}$ versus $400 \mathrm{mg} / \mathrm{d}$ versus $400 \mathrm{mg} / \mathrm{d}$ plus interferon in newly diagnosed chronic myeloid leukemia. J Clin Oncol. 2011; 29 (12): 1634-1642.

11. Hehlmann R, Mueller MC, Lauseker M, Hanfstein B, Fabarius A, Schreiber A, Proetel U, Pletsch N, Pfirrmann M, Haferlach C, Schnittger S, Einssele H, Dengler J, Falge C, Kanz L, Neubauer A, Kneba M, Stegelmann F, Pfreundschuh M, Waller CF, Spiekermann K, Baerlocher GM, Ehninger G, Heim D, Heimpel H, Nerl C, Krause SW, Hossfeld DK, Kolb HJ, Hasford J, Saussele S, Hochhaus A. Deep molecular response is reached by the majority of patients treated with imatinib, predicts survival, and is achieved more quickly by optimized high-dose imatinib: results from the randomized CML-study IV. J Clin Oncol. 2014; 32 (5): 415-423.

12. Hoffmann VS, Hasford J, Hehlmann R. Systematic Review and Meta-Analysis of Randomized Trials Comparing Imatinib $400 \mathrm{Mg} / \mathrm{d} \mathrm{Vs}$. Imatinib $800 \mathrm{Mg} / \mathrm{d}$, and Imatinib $400 \mathrm{Mg} / \mathrm{d}$ Vs. Second Generation TKIs in Chronic Phase CML-Patients. Proc. ASH, 2015. Abstract \# 2787

13. Hughes TP, Lipton JH, Spector N, Cervantes F, Pasquini R, Clementino NC, Dorlhiac Llacer PE, Schwarer AP, Mahon FX, Rea D, Branford S, Purkayastha D, Collins L, Szczudlo T, Leber B. Deep molecular responses achieved in patients with CML-CP who are switched to nilotinib after long-term imatinib. Blood 2014; 124 (5): 729-736.
14. Jabbour E, Cortes J, Santos FP, Jones D, O’Brien S, Rondon G, Popat U, Giralt S, Kebriaei P, Jones RB, Kantarjian H, Champlin R, de Lima M. Results of allogeneic hematopoietic stem cell transplantation for chronic myelogenous leukemia patients who failed tyrosine kinase inhibitors after developing BCR-ABL1 kinase domain mutations. Blood 2011; 117 (13): 3641-3647.

15. Jiang Q, Xu LP, Liu DH, Liu KY, Chen SS, Jiang B, Jiang $\mathrm{H}$, Chen $\mathrm{H}$, Chen $\mathrm{YH}$, Han $\mathrm{W}$, Zhang $\mathrm{XH}$, Wang $\mathrm{Y}$, Qin YZ, Liu YR, Lai YY, Huang XJ. Imatinib mesylate versus allogeneic hematopoietic stem cell transplantation for patients with chronic myelogenous leukemia in the accelerated phase. Blood 2011; 117 (11): 3032-3040.

16. Kantarjian H, Shah NP, Hochhaus A, Cortes J, Shah S, Ayala M, Moiraghi B, Shen Z, Mayer J, Pasquini R, Nakamae $\mathrm{H}$, Huguet $\mathrm{F}$ et al. Dasatinib versus imatinib in newly diagnosed chronic-phase chronic myeloid leukemia. N Engl J Med. 2010; 362 (24): 2260-2270.

17. Khoury HJ, Kukreja M, Goldman JM, Wang T, Halter J, Arora M, Gupta V, Rizzieri DA, George B, Keating A, Gale RP, Marks DI, McCarthy PL, Woolfrey A, Szer J, Giralt SA, Maziarz RT, Cortes J, Horowitz MM, Lee SJ. Prognostic factors for outcomes in allogeneic transplantation for CML in the imatinib era: a CIBMTR analysis. Bone Marrow Transplant. 2012; 47 (6): 810-816.

18. Palandri F, Castagnetti F, Alimena G, Testoni N, Breccia M, Luatti S, Rege-Cambrin G, Stagno F, Specchia G, Martino B, Levato L, Merante S, Liberati AM, Pane F, Saglio G, Alberti D, Martinelli G, Baccarani M, Rosti G. The long-term durability of cytogenetic responses in patients with accelerated phase chronic myeloid leukemia treated with imatinib 600 mg: the GIMEMA CML Working Party experience after a 7-year follow-up. Haematologica 2009; 94 (2): 205-212.

19. Radich JP, Kopecky KJ, Appelbaum FR, Kamel-Reid S, Stock W, Malnassy G, Paietta E, Wadleigh M, Larson RA, Emanuel P, Tallman M, Lipton J, Turner AR, Deininger M, Druker BJ. A randomized trial of dasatinib $100 \mathrm{mg}$ versus imatinib $400 \mathrm{mg}$ in newly diagnosed chronic-phase chronic myeloid leukemia. Blood 2012; 120 (19): 3898-3905.

20. Saglio G, Kim DW, Issaragrisil S, le Coutre P, Etienne G, Lobo C, Pasquini R, Clark RE, Hochhaus A, Hughes TP, Gallagher N, Hoenekopp A, Dong M, Haque A, Larson RA, Kantarjian HM; ENESTnd Investigators. Nilotinib versus imatinib for newly diagnosed chronic myeloid leukemia. N Engl J Med. 2010; 362 (24): 2251-2259.

21. Saussele S, Lauseker M, Gratwohl A, Beelen DW, Bunjes D, Schwerdtfeger R, Kolb HJ, Ho AD, Falge C, Holler E, Schlimok G, Zander AR, Arnold R, Kanz L, Dengler R, Haferlach C, Schlegelberger B, Pfirrmann M, Mueller MC, Schnittger S, Leitner A, Pletsch N, Hochhaus A, Hasford J, Hehlmann R; German CML Study Group. Allogeneic hematopoietic stem cell transplantation (allo SCT) for chronic myeloid leukemia in the imatinib era: evaluation of its impact within a subgroup of the randomized German CML Study IV. Blood 2010; 115 (10): 1880-1885. 
22. Saussele S, Lauseker M, Mueller MC, Gratwohl A, Beelen DW, Bunjes D, Schwerdtfeger R, Kolb, H-J, Ho AD, Falge Ch, Holler E, Schlimok G, Zander AR, Arnold R, Kanz L, Dengler R, Haferlach C, Schlegelberger B, Schnittger S, Kalmanti L, Proetel U, Hanfstein B, Hasford J, Hochhaus A, Pfirrmann M, and Hehlmann R for the German CML-Study Group. Allogeneic hematopoietic stem cell transplantation (HSCT) in chronic myeloid leukemia after imatinib failure; updated results of the German CML Study IV. Proc. ASH 2014. Abstr. \# 155.
23. Yeung DT, Osborn MP, White DL, Branford S, Braley J, Herschtal A, Kornhauser M, Issa S, Hiwase DK, Hertzberg M, Schwarer AP, Filshie R, Arthur CK, Kwan YL, Trotman J, Forsyth CJ, Taper J, Ross DM, Beresford J, Tam C, Mills AK, Grigg AP, Hughes TP; Australasian Leukaemia and Lymphoma Group. TIDEL-II: first-line use of Imatinib in CML with early switch to nilotinib for failure to achieve time-dependent molecular targets. Blood 2015; 125 (6): 915923.

\section{Стратегии первой и второй линии в лечении хронического миелоидного лейкоза (хроническая фаза), включая трансплантацию гемопоэтических клеток}

Рюдигер Хельманн, Сусанна Саусселе

Гейдельбергский университет, Германия

\section{Резюме}

Обзорная статья посвящена принципам современной терапии при хроническом миелоидном лейкозе (ХМЛ). В настоящее время возможности терапии в хронической фазе ХМЛ предусматривают применение иматиниба в стандартных или высоких дозах (400-800 мг/сут.) и ингибиторов тирозинкиназы (ИТК) второго поколения (дазатиниб и нилотиниб). Трансплантация гемопоэтических стволовых клеток (ТГСК) рассматривается в качестве 2-й и 3-й линий лечения. ТГСК в ранние сроки может быть эффективна для больных невысокой степени риска и с низким риском исходов самой трансплантации. По данным германской группы исследований ХМЛ, 10-летняя выживаемость пациентов значительно улучшилась (до 85\%) с введением иматиниба. Ранее выживаемость достигалась в основном за счет применения ТГСК. Программы исследования CML III и CML IIIA сравнивали алло-ТГСК с наилучшим доступным лекарственным лечением. Большинство авторов, применявших ИТК при ХМЛ, использовали иматиниб и, в ряде ситуаций - ТГСК. Согласно результатам CML-Study IV, молекулярные ответы (MO) с примененем иматиниба для ситуаций с MP2 (цитогенетическая ремиссия) могут достигать $92 \%$ после 10 лет наблюдений. Внедрение ИТК второго поколения (дазатиниб и нилотиниб) связано с большей частотой молекулярных ремиссий (DASISION, 5-летние результаты, а также ENESTnd- 5 лет). Повышение дозы иматиниба до 800 мг также дает более скорые и глубокие молекулярные ответы, при сравнении лечения иматинибом в дозах 400 и 800 мг. Мета-анализы соответствующих рандомизированных исследований показали повышение на $45 \%$ частоты молекулярной ремиссии через 12 мес. с 800 мг иматиниба по сравнению с 400 мг иматиниба в сутки ( $\mathrm{p}=0,0088)$. Предполагается также, что из анализа прогноза больных в различных исследованиях можно заключить, что частота молекулярных ремиссий сравнима при использовании иматиниба (800 мг/сут.) ИТК второго поколения.

Стратегии второй линии терапии применяются в случаях непереносимости или резистентности к препаратам. Тогда рекомендуется переход на ИТК второго ряда и/или аллогенная ТГСК. В исследовании ENESTcmr Study (Hughes et al., 2014) показано, что этот переход приводил к большему числу молекулярных ремиссий BCR-ABL, чем при постоянной терапии иматинибом ( $\mathrm{p}=0,009)$. Наилучшие подходы с лекарственной терапией и применением ТГСК в различных фазах ХМЛ описаны в работах последних лет (Jiang et al., 2011; Jabbour et al., 2011, Khoury et al., 2012; Saußele et al., 2014). Так, хороший эффект от алло-ТГСК показан в работе Saußele et al., 2014, при среднем сроке наблюдения 78,5 мес. Пациентов классифицировали по степени риска. ТГСК проводили в 1-й хронической фазе элективно или при резистентности к ИТК, и показали 80\%-ную выживаемость через 5 лет. Интересно, что 
вероятность выживания пациентов, трансплантированных в ранней хронической фазе ХМЛ была сходной с таковой после лечения только иматинибом.

\section{Выводы}

1. Современное лечение первой линии при ХМЛ включает иматиниб, нилотиниб и дазатиниб.

2. Доля пацентов, достигающих молекулярной ремиссии к 12 мес., сходна для больных, получавших оптимизированные дозы иматиниба и ИТК 2-го поколения.

3. ТГСК является методом выбора для второй линии терапии.
4. Долгосрочные исходы после ранней ТГСК в хронической фазе сходны с результатами, полученными с иматинибом.

5. ТГСК на ранних сроках можно рассматривать при лечении пациентов с ХМЛ (хроническая фаза) невысокой степени риска.

\section{Ключевые слова}

хронический миелоидный лейкоз, хроническая фаза, терапия, ингибиторы тирозинкиназы, трансплантация гемопоэтических клеток 